\title{
WPLYW ASPEKTÓW FUNKCJONALNYCH, EKONOMICZNYCH I PSYCHOLOGICZNYCH NA OKNO MUZEALNE W ZABYTKOWYM BUDYNKU POPRZEMYSŁOWYM
}

\begin{abstract}
Projektowanie, budowa i organizacja muzeum w zabytkowych budynkach poprzemysłowych to proces wielowątkowy i skomplikowany. Wymaga też szerokiego kompromisu pomiędzy pragnieniem zachowania historycznej przestrzeni w możliwie niezmienionej formie a chęcią zapewnienia optymalnych warunków samej ekspozycji i ją oglądającym. Jeden z takich dylematów dotyczy problematyki związanej z oknami. Oprócz czynników prawnych równie ważne są aspekty użyteczności, ekonomii i zagadnienia psychologii percepcji ekspozycji, i dlatego to na nich skupi się ten artykuł. Przedstawione zostaną w nim najważniejsze zagadnienia usprawniające zarówno proces budowlany, jak i późniejsze wieloaspektowe funkcjonowanie muzeum. Zagadnienie to zostanie omówione na przykładzie wybranych polskich muzeów, które w latach 2004-2015 powstały w budynkach poprzemysłowych.
\end{abstract}

Słowa kluczowe: okno, zabytek przemysłu, adaptacja, muzeum, estetyka, ekonomia, percepcja ekspozycji

\section{Wstęp}

Przystosowanie zabytku techniki dla potrzeb muzealnych to skomplikowany i wielowarstwowy problem. Adaptacja takiego obiektu jest zwykle omawiana jako zjawisko dotyczące całości budynku; omawia się przeważnie jej kontekst społeczny, urbanistyczny, historyczny lub skupia się na konkretnej grupie zabytków, np. wieżach ciśnień czy też na ich docelowej funkcji. W niniejszym artykule zastosowano jednak podejście odmienne, a celem tego studium jest naświetlenie konkretnego problemu projektowego, jakim jest zagadnienie okna muzealnego w obiekcie poprzemysłowym. Tekst ten zredagowano w oparciu o polskie przykłady adaptacji, w których interwencje budowlane zostały podjęte w latach 2004-2015. Opis nie odnosi się do zagadnień prawnych, ta tematyka została zarysowana w osobnym artykule zatytułowanym „Gdy okno zabytku przemysłu

\footnotetext{
${ }^{1}$ Marta Rusnak Katedra Historii Architektury Sztuki i Techniki, Politechnika Wrocławska, marta.rusnak@pwr.edu.pl
} 
staje się oknem muzealnym. Streszczenie sytuacji prawnej”. Przedstawione poniżej opracowanie dotyczy zagadnień związanych z ekonomią, funkcjonalnością i psychologii percepcji. Wymienione elementy mogą mieć zasadniczy wpływ na działania podejmowane w odniesieniu do zabytkowych przegród budowlanych.

\section{Użyteczność i funkcjonalność}

\subsection{Elastyczność przestrzeni ekspozycyjnej}

Niezbędnym do omówienia, choć z pozoru może banalnym zagadnieniem, jest konieczność znalezienia w muzeum płaszczyzny dla powieszenia obrazu lub wydzielenia kubatury dla określonej wielości rzeźby. Okna w budynkach poprzemysłowych, ich liczba, dyspozycja i powierzchnia mogą po tym względem znacząco ograniczać ekspozycyjną funkcjonalność wnętrza. Choć jest to problem dotyczący różnych grup rewitalizowanych zabytków, w przypadku fabryk jest to szczególnie duże wyzwanie projektowe. W części z nich tak jak np. w Galerii Sztuki będącej oddziałem Muzeum im. Leona Wyczółkowskiego w Bydgoszczy spora część okien została zasłonięta ekranami i roletami. W podobny sposób zamontowane na równi $\mathrm{z}$ wewnętrznym licem ściany rolety wykorzystuje się dla potrzeb częstych zmian aranżacji w budynku D w Centralnym Muzeum Włókiennictwa. W tym muzeum zasłonięciu nie podlegają wszystkie okna, dzięki czemu z zewnątrz nie powstaje wrażenia nieużytkowanego lub niedostępnego wnętrza. Takie przykre wrażenie można natomiast odnieść, zbliżając się do oddziału Muzeum Historii Miasta Krakowa mieszczącego się w tzw. Fabryce Schindlera.

Innym rozwiązaniem jest zamurowanie części okien, do czego doszło w MS2 w Łodzi. Na elewacji północnej w pełni zaślepiono 18 z 21 pierwotnych osi okiennych, także kilka innych okien, uzyskując od wewnątrz długą niepodzieloną elementami architektonicznymi ścianę, co z pewnością ułatwia aranżacje wystaw. Od zewnątrz zaślepione fragmenty przykryto pojedynczym przeszkleniem opatrzonym podziałami kopiującymi te pierwotne. Ze względu na sąsiedztwo dużej galerii handlowej na tę elewację patrzy się zazwyczaj pod dużym kontem, dlatego uzyskano zaplanowaną iluzję. Z niektórych miejsc rozwiązanie wygada jednak mało atrakcyjnie. Taka decyzja może budzić kontrowersje, choć obok wspomnianego już wcześniej wpływu na przestrzeń ekspozycyjną jest podyktowana także chęcią zasłonięcia estetycznie wątpliwego widoku: okna wychodziłyby na dach centrum handlowego pełen urządzeń technicznych. Ponadto bardzo istotnym jeśli nie najistotniejszym - argumentem była w tym przypadku potrzeba jak najpełniejszego, ekonomicznego wykorzystania przestrzeni sąsiadującego z muzeum centrum handlowego. W tym celu należało uzyskać ścianę o wysokiej izolacyjności pożarowej, a zamurowanie okien okazało się w tym przypadku najtańszym rozwiązaniem. Szkoda, że przy tak wielkich zmianach, konserwator nie wymógł na inwestorze użycia oryginalnych elementów demontowanych z tej lub przeciwległej elewacji, zamiast wykonywania nowego sztafażu architektonicznego. Argumentami przemawiającymi za ponownym wykorzystaniem starych ram okien- 
nych powinny być ekologia oraz niższy koszt inwestycji. Gmach łódzkiego muzeum jest jednym z najbardziej swobodnie modyfikowanych zabytków. Do zamurowania kolejnych otworów przyczyniła się chęć umieszczenia przy nich szaf transformatorowych, a także wykorzystanie kilku okien w charakterze gablot reklamowych. Ten przykład pokazuje jak różne aspekty funkcjonowania muzeum stają się powodem wieloaspektowej utraty autentyzmu elewacji [8].

Odmienną taktykę, choć nie oderwaną od aspektów funkcjonalnych, obrano w Muzeum Wisły w Tczewie i przylegającej do niej Fabryce Sztuki, której budynek przypomina pierwotny układ tkalni zaadaptowanej na MS2. W Tczewie postarano się powstrzymać przed trwałymi interwencjami, a także zrównoważyć modyfikacje $\mathrm{z}$ zabiegami konserwatorskimi. W fabryce nie zamurowano żadnego okna, zachowując od zewnątrz stalowe ramy zabytkowego układu. Nowe okna, dodane od wewnętrznej strony, wyposażono w dwudzielne rolety. Głębokie nisze okienne są wykorzystywane jako otwierane lub zamykane na światło dzienne gabloty ekspozycyjne. Nie można tam jednak umieścić kolekcji o dowolnych rozmiarach, co z pewnością chciano osiągnąć w muzeum łódzkim.

Innym sposobem zwiększenia funkcjonalnej elastyczności zabytkowego wnętrza, poprzez uniezależnienie się rytmu podziałów okiennych, jest zastosowanie logiki „box in box”, wedle której zabytkowy budynek staje się płaszczem okalającym wewnętrzną strukturę. Tak transformowany obiekt musi posiadać na tyle duże rozmiary, aby uzyskana przestrzeń wewnętrznego pudła była w dalszym ciągu atrakcyjna. W polskich muzeach nie spotkamy takiego rozwiązania projektowego służącemu zachowaniu autentyzmu zabytkowych okien, natomiast przykładem tej logiki są wysokie parawany otaczające sale ekspozycyjne Fundacji Art Stations Foundation na terenie Starego Browaru w Poznaniu, czy przystawione bezpośrednio do okien zabudowy gipsowo-kartonowe w Mazowieckim Centrum „Elektrownia” w Radomiu. Rozwiązania te nie były jednak w żaden sposób powiązane z chęcią zachowania oryginalnych przeszkleń.

Omawiany efekt kompromisu pomiędzy funkcjonalnością a konserwatorską perfekcją wyrażający się w logice „box in box” najpełniej widać na zagranicznym w tym wypadku przykładzie Muzeum Sztuki Współczesnej w Cottbus. Wiąże się to $\mathrm{z}$ uniezależnieniem wymagań dotyczących zabytku nieruchomego i wymagań sformowanych tak, aby zabezpieczyć kolekcję. ${ }^{2}$

\subsection{Okno a percepcja wystawy}

Wielokrotnie chęć odsunięcia eksponatu od okna lub stworzenia wystawy pozbawionej możliwości wyglądnięcia na zewnątrz obiektu podyktowana jest chęcią wyeliminowania z ekspozycji elementów, które wizualnie mogłyby odwracać uwagę widza od kolekcji. „Zależność ta dotyczy szczególnie obrazu, który swą ramą odcina się od rzeczywistości, wykrawa z niej niejako okno, pozwalające zajrzeć do innego świata" [1]. Skoro kurator chce budować w widzu pewne po-

${ }^{2}$ Chodzi także o ograniczanie promieniowania UV, kontrolę wilgotności, temperatury oraz jakości powietrza. 
znawcze napięcie, może dążyć do tego aby inne perspektywy poznawcze nie przeszkadzały w percepcji wystawy. Dotyczy to zarówno tych okien, z których widok jest szczególnie atrakcyjny, jak i tych, które pokazują szarą rzeczywistość (rys. 1). Po raz kolejny łódzkie MS2 staje się znakomitym przykładem, gdyż wspomniane w poprzednim punkcie zamurowane okna uniemożliwiają spoglądanie tak na dachy centrum handlowego, jak i na masy ludzi zaaferowanych konsumpcją. Jednocześnie twórcy muzeum zadbali o psychiczny komfort zwiedzających, którzy potrzebują odpoczynku dla oczu i nóg - zachowane okna pozwalają na krótki oddech od zamkniętej przestrzeni ekspozycyjnej i wyglądnięcie na najmniej ruchliwą ulicę.

Podobna chęć stworzenia innego, odciętego od rzeczywistości świata, może się pojawić w muzeach $\mathrm{z}$ wystawami o charakterze narracyjnym lub w centrach edukacyjnych, wyposażonych w liczne, często widowiskowe albo wręcz krzykliwe multimedia. Dzieje się tak z kilku względów. Po pierwsze, jeśli celem jest zbudowanie iluzji podróży w czasie, okna wychodzące na świat zewnętrzny zaburzałyby tę teatralizującą kreację. Przykładem takiego rozwiązania jest Muzeum Browaru Żywiec. Ten sam mechanizm sugeruje wykreowanie atmosfery intelektualnego skupienia w naukowych ,black spaces” [2]. W takich miejscach duża liczba ruchomych elementów i miejsc wykonywania doświadczeń zazwyczaj sugeruje, tak jak w Młynie Wiedzy w Toruniu, wizualne odcięcie strefy ekspozycji od świata zewnętrznego.

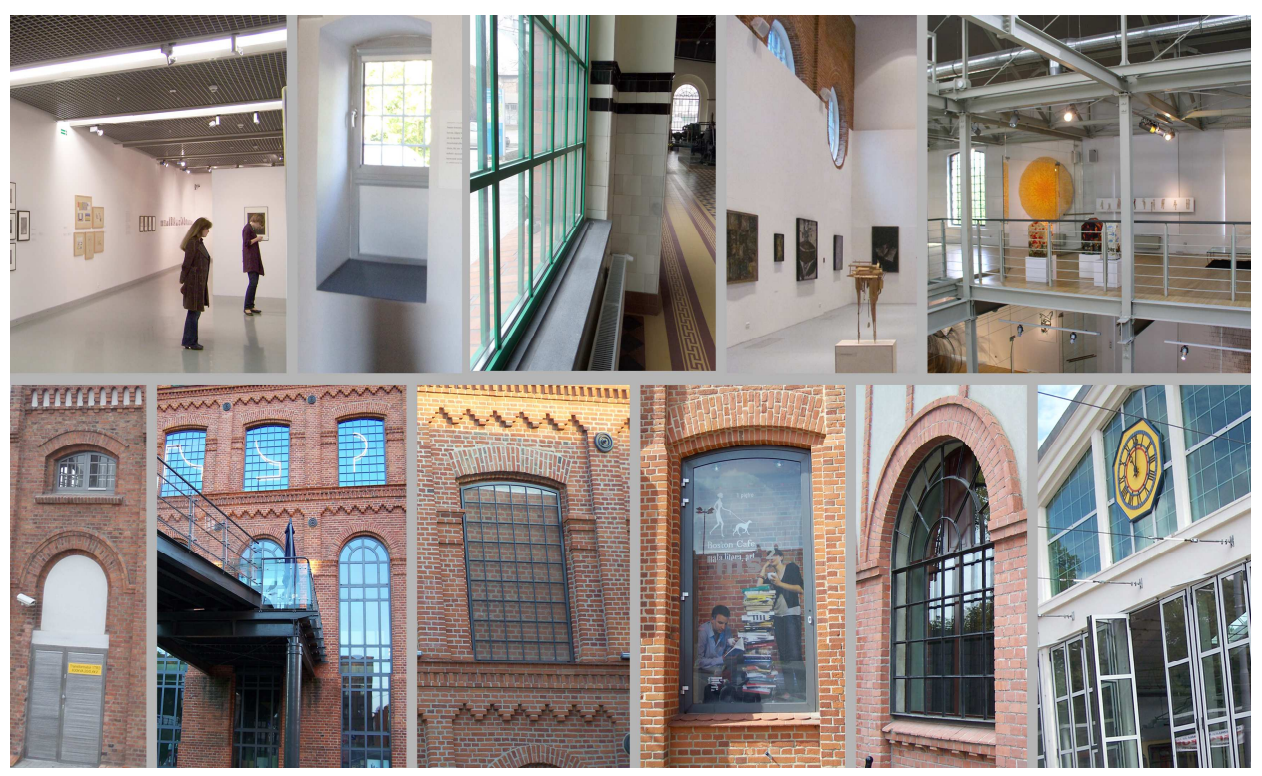

Rys. 1. Okna w obiektach poprzemysłowych adaptowanych na muzea. Górny rząd - wnętrza. Dolny rząd fragmenty elewacji. (kolejno: A.MS2 - brak śladu okien, B. Muzeum Wisły, C. „Elektrownia” w Czeladzi, D. Elektrownia w Radomiu, E. Centralne Muzeum Włókiennictwa, bud D, F. Nowe Muzeum Śląskie, G.-H. MS2, 10. Muzeum powstania Warszawskiego, I. „Zajezdnia Sztuki” w Szczecinie)

Fig. 1. Windows in postindustrial monuments transformed into museums. Higer - insides. Lower - outside 


\subsection{Zmiana wymiarów okna}

Kolejną potrzebą w muzeum jest wygenerowanie strefy wejściowej adekwatnej do liczby zwiedzających i do rangi lub aspiracji inwestora. Przykładem takiej zmiany jest interwencja w Centralnym Muzeum Włókiennictwa w Łodzi. Tego typu modyfikacje są konsekwencją urbanistycznej ewolucji otoczenia budynku, ale mogą być również podyktowane, tak jak w MS2, pragnieniem otwarcia się na pieszych napływających z dwóch niemal równoprawnych kierunków. Od północy, od strony placu, w trzech skrajnych osiach usunięto podokienniki i jeden pas nadproży. W efekcie uzyskano wysokie na dwie kondygnacje przeszklenia sygnalizujące miejsce wejścia do wysokiego holu. Od przeciwległej strony dostęp na drugą kondygnację wprost do muzealnej kawiarni, gwarantuje kładka prowadząca poprzez kolejne przekształcone fragmenty elewacji. Elementem, który podkreśla interwencję, jest zmiana rysunku okna oraz proporcji profili tych przeszkleń. Wysokie przeszklenia o równie smukłych ramach i szprosach, najpewniej były bardzo drogie do wykonania lub żadna $\mathrm{z}$ firm podwykonawczych nie posiadała technologii odpowiedniej do wykonania takiego przeszklenia.

Ze względów funkcjonalnych do usuwania podokienników dochodzi niezwykle często szczególnie w budynkach, w których adaptacja polega wyłącznie na przebudowie wnętrza. Sytuacją korzystną dla zachowania oryginalnych proporcji otworów okiennych może się okazać kubaturowa rozbudowa zabytku połączona z wykreowaniem strefy wejściowej w nowej części. Tak postąpiono w Mazowieckim Centrum Sztuki Nowoczesnej w Radomiu i w Galerii „Elektrownia” w Czeladzi.

\section{Ekonomia w muzeum a okno muzealne}

\subsection{Wymiana czy zachowanie}

Zagadnienie finansowania muzeów zostało pod wieloma względami omówione $\mathrm{w}$ publikacji [3]. Temat ten w dalszym ciągu wymaga badań, o czym mogą świadczyć chociażby kontrowersje, które budzi zagadnienie opłacalności lokowania muzeów w obiektach zabytkowych. Głos w tej sprawie zabrał między innymi Andrzej Kicinski twierdzący, iż adaptacja obiektu zabytkowego jest tańsza i mniej czasochłonna niż wzniesienie nowego obiektu [4]. Wypowiedział się na ten temat także Jerzy Ebing, według którego odmienne oczekiwania inwestora, użytkownika i konserwatora podwyższają koszty o 50 a nawet $100 \%$ [5]. Według przeprowadzonych badań wzniesienie jednego metra kwadratowego nowego obiektu muzealnego w Polsce to koszt od $3800 \mathrm{zt} / \mathrm{m} 2$ do $13500 \mathrm{zt} / \mathrm{m} 2$. Adaptacja budynków poprzemysłowych to wydatek od $2900 \mathrm{zz} / \mathrm{m} 2$ do prawie $10600 \mathrm{zt} / \mathrm{m} 2$. Dalsze rachunki, oparte o polskie realizacje przeprowadzone w latach 2004-2014, wykazały, że średni koszt wzniesienia jednego metra kwadratowego nowego muzeum i adaptacji obiektu poprzemysłowego to niemal te same kwoty, a dokładnie około 8 tysięcy złotych [6]. Koszty wielu adaptacji byłyby jednak znacznie wyższe, gdyby większy nacisk położono na jakość prowadzonych przy nich zabiegów konserwatorskich. Zastrzeżenia budzą przede wszystkim przypadki, w których zrezy- 
gnowano z zachowania oryginalnych detali. $\mathrm{W}$ około $60 \%$ badanych muzeów stare okna wymieniono na nowe. W tych przypadkach zysk ze sprzedaży pofabrycznego złomu mógł przynajmniej częściowo rekompensować koszt demontażu. Wymiana tych okien będzie droższa niż instalacja okien w zupełnie nowym gmachu jedynie ze względu na konieczność skopiowania pierwotnych podziałów poprzez wprowadzenie dodatkowych szprosów lub wykonanie wieńczącego je łuku.

Inne rozwiązania dotyczące okna muzealnego, uwzględniające nie tylko wizualny aspekt zachowania zabytku, są jednak droższe niż wykonanie nowej przegrody. Staranne oczyszczenie, malowanie, nowe szklenie, wykonanie krat antywłamaniowych niewątpliwie zwiększa koszty inwestycji. Wydawać by się mogło, że bardziej kosztowne powinny być te realizacje, w których zastosuje się zdwojony układ zachowujący dawne okno przy jednoczesnym zastosowaniu nowego wewnętrznego skrzydła. Nie jest to jednak pewne, gdyż przy zachowaniu zabytkowego okna estetyczne oczekiwania dotyczące nowej części są znacznie mniejsze. Takie okno nie musi mieć specjalnych ram i indywidualnie zamawianych profilów szprosów. Jednocześnie wydłuża się lista firm mogących dostarczyć takie okno, co także powinno obniżyć koszty. Potwierdzają to przykłady z tczewskiego Muzeum Wisły i Muzeum Powstania Warszawskiego, w których sprawnie rozwiązano problem koegzystencji starej i nowej przegrody.

W przypadku całkowitego uwolnienia się od poglądu, iż zabytek a także muzeum muszą odpowiadać tym samym kanonom estetycznym co nowy budynek koszty inwestycji gwałtownie maleją. Świadczy o tym przykład oddziału Muzeum im. Leona Wyczółkowskiego „Explozeum” w Bydgoszczy, w którym wykonano nowe okna, a te zachowane jedynie zabezpieczono przed dalszą korozją, nie wykonując w nich uzupełnień i korekt geometrii. Zabezpieczeniu uległy jedynie elementy opraw okiennych stwarzające ryzyko zranienia nieuważnego użytkownika. Koszt tej adaptacji wyniósł jedynie 2 900zł/m2. W innych przypadkach, szczególnie tam gdzie presja ujednolicenia elewacji była duża, zwiększanie skali finansowania okazywało się odwrotnie proporcjonalne względem zachowania autentyzmu zabytku.

\subsection{Koszty eksploatacji}

Odrębnym aspektem ekonomicznym są koszty eksploatacji. Przyjmując wyłącznie to kryterium, logika nakazywałby wymianę starych okien na nowe. Nieekonomiczne jest dogrzewanie lub obniżanie temperatur w pomieszczeniach, w których nie wymieniono okien zgadzając się na ich niską izolacyjność termiczną. Bardziej kosztowne jest utrzymywanie zabytkowego okna w satysfakcjonującym stanie technicznym i wizualnym. W przypadku zdwojenia układu okiennego, zachowanie oryginału przy jednoczesnym wstawieniu nowego okna, także okazuje się rozwiązaniem droższym i mniej wygodnym w konserwacji. Problemy może sprawiać chociażby sposób czyszczenia takich wieloelementowych detali. Z drugiej strony i z tym aspektem część projektantów poradziła sobie wyśmienicie. W Muzeum Powstania Warszawskiego pozbawioną szyb ramę wymontowano przesuwając ją znacznie w stronę lica muru, $\mathrm{z}$ tyłu zaś zamontowano okna o no- 
wych podziałach. Pochyły profil ceramicznych podokienników wraz z przesunięciem umożliwił bezkolizyjnie odprowadzanie wody z opadów atmosferycznych jak i mycie, gdyż okna znajdują się na parterze. Natomiast w Muzeum Wisły w Tczewie stare ramy zamontowano na styk, ale nowe okna są w pełni otwierane, a w celu odprowadzenia wody skrócono jedną ze środkowych kwater.

\subsection{Estetyka budynku a jego potencjał marketingowy}

W większości adaptowanych fabryk, w momencie podjęcia rewitalizacji nie wszystkie okna są w tym samym stanie. Najczęściej duży odsetek jest uszkodzony, inne stały się łupem złomiarzy lub zostały wyparte przez plastikowych następców jeszcze zanim zyskały rangę zabytkowych. Ten stan rzeczy często zniechęca projektantów i konserwatorów do poszukiwania indywidualnych rozwiązań. Odstręczać to może również przyszłych użytkowników, którzy nie są skorzy do estetycznego kompromisu idącego za patchworkowym zestawieniem starych i nowych okien, jaki można zaobserwować na przykład w Mazowieckim Centrum Sztuki „Elektrownia” w Radomiu - występuje tam zabytkowa stolarka, okna drewniane oraz okna wymienione w latach 90-tych XX wieku. Wynika to z przekonania, że wizualna atrakcyjność obiektu przełoży się na zainteresowanie ekspozycją kryjącą się wewnątrz.

Fabryka, a szczególnie ta XIX wieczna, nie zawsze kojarzy się z czystą bielą, błyskiem metalu, przejrzystymi lub lustrzanymi oknami. Wiele procesów produkcji wiązało się z dużym zapyleniem. To aspekt estetycznie utrudniający starania konserwatorów o zachowanie oryginalnej struktury. Powyginane, wyszczerbione, pożółkłe, popękane, zardzewiałe elementy mogą nie odpowiadać oczekiwaniom inwestorów, którzy czasem chcieliby zamiast zabytku posiadać lub zarządzać nowym, $\mathrm{z}$ wszech miar nowoczesnym gmachem. Chęć ujednolicenia lub zmiany wyglądu elewacji może być motywowana przez ambicje wytworzenia architektonicznej ikony miasta, posiadającej silny potencjał marketingowy. W tym momencie trudno jest mówić o wypracowanym konsensusie funkcjonalno-ekonomiczno-konserwatorskim.

Czasem jednak efekt plastikowego zabytku jest wynikiem pośpiechu, nieprzemyślanych decyzji, niedorachowania inwestycji lub braku doświadczenia. Co łatwo zaobserwować przyglądając się fasadzie „Zajezdni Sztuki” w Szczecinie.

\section{Podsumowanie}

W efekcie podejmowanych kompromisów adaptacyjnych żadne ze środowisk zaangażowanych $w$ ten proces nie jest w pełni zadowolone. Architektom brakuje nowych wyzwań. Muzealnicy chcieliby uwolnić się od ciężaru zależności od zabytkowej struktury i dyskomfortu związanego z użytkowaniem nieidealnego narzędzia przechowywania zbiorów. Najbardziej jednak niezadowoloną grupą jest środowisko konserwatorskie, ,które ma prawo czuć się ignorowane” [7]. Ich racje, mimo że wyraźnie zapisane w ustawach i rozporządzeniach, nie są w stanie pokonać ekonomicznego i najczęściej zdroworozsądkowego nacisku ze strony tych, którzy w inny sposób wyznaczyli swoje priorytety. Wydaje się, że nawet najlepsze 
prawo nie jest w stanie zmienić tego stanu. Drogą do innego prowadzenia rozmów, w wyniku których podejmowane będą rzeczywiste kompromisy, to próba wzajemnego odkrycia logiki innych grup zawodowych. Problem braku porozumienia dotyczy zarówno ogólnego pojmowania zjawiska adaptacji jak i detali, w tym wypadku okien. W budowaniu zrozumienia pomiędzy tymi środowiskami pomocną byłaby całkowita przejrzystość procesów uzyskiwania odstępstw od przepisów budowlanych i procedur konsultacji z Konserwatorem Zabytków. Znając pełną argumentację byłoby nam łatwiej zrozumieć racje innych ekspertów. Jest to tym bardziej uzasadnione, jeżeli dotyczy rewitalizacji subwencjonowanych ze środków publicznych, a także muzeów, które w Polsce są w większości placówkami publicznymi.

\section{Literatura}

[1] Modyński K, Percepcja wystawy a kształtowanie przestrzeni ekspozycyjnej, Muzealnictwo 2015 (56) s. 150.

[2] Toon R., Black box science In Black box centres, w: Ed. Susanne MacLeond, Reshaping Museum Space, architecture, design, exhibitions, s. 26-38.

[3] Ekonomia Muzeum, red. Folga-Januszewska D., Bartłomiej Gutowski, Warszawa 2011.

[4] Kiciński A., Muzea. Strategie i dylematy rozwoju, Warszawa 2004, s. 76.

[5] Ebing J. S. Nowe funkcje budowli inżynierskich w: „Zawód: Architekt” 01.2010.

[6] Rusnak M, Ekonomia transformacji obiektów poprzemysłowych dla potrzeb muzealnych i ekspozycyjnych w Polsce w latach 2000-20014, w: Miasto przyjazne mieszkańcom, Pro-Revita Łódź 2016, s. 46-68.

[7] Szmygin B. red., Wartość funkcji w obiektach zabytkowych, PKN ICOMOS, Muzeum Pałac w Wilanowie, Warszawa 2014.

[8] Walczak B., Kurzac A., Problems of restoration of window frames in the $19^{\text {th }}$ century industrial facilities on the example of Łódź, w: Civil and Enviromental Enginering Reports, No. 9 2012, s. 153-164.

\section{THE IMPACT OF FUNCTIONALITY, ECONOMY, AND PSYCHOLOGY ON THE MUSEUM WINDOW IN HISTORIC POSTINDUSTRIAL BUILDINGS}

\section{S u m m a r y}

The design, construction and arrangement of a museum in historical postindustrial buildings is a complex, multifaceted process. It often requires a serious compromise between the desire to keep the original building intact and the need to provide both the exhibition and the visitors with the most convenient and suitable conditions. One of such dilemmas is related to the problem of windows. Apart from legal issues, one should bear in mind problems of functionality, economy and psychology of perception, and that is why they will be the focus point of this paper. What will be presented are the most important features related both to the construction process and the further, multilayered functioning of the museum. The issue will be analyzed with reference to different solutions that were applied in Polish investments in the years 2004-2015.

Keywords: window, adaptation, museum, postindustrial buildings, aesthetics, economy, exhibition perception

Przestano do redakcji: $2.06 .2017 \mathrm{r}$.

Przyjęto do druku: 30.06 .2017 r. 